Araştırma Makalesi

\title{
Bilecik için POTGTG Santralinin Potansiyel Değerlendirilmesi
}

Geliş / Received: 30/12/2019

\author{
Damla KILIÇ ${ }^{1 *}$, Oğuz ARSLAN ${ }^{2}$
}

ÖZ

Revize / Revised: 28/01/2020

Kabul / Accepted: 05/02/2020

Bu çalışmada, düşük güneş ışınımı değerine sahip bir bölge için güneș santrali tasarımı yapılmıștır. Tasarlanan Parabolik Oluk Tipi Güneş Termal Güç (POTGTG) santralinde Organik Rankine Çevrimine (ORC) göre çalışan bir sistem göz önüne alınmıştır. POTGTG santralinin tasarımında Bilecik’in güneş 1şınımı değerleri dikkate alınmıştır. Sistem, Güneş Alanı (GA), Termal Enerji Depolama (TED) sistemi ve Güç Bloğundan (GB) oluşmaktadır. Çalışma sıvısı olarak GA, TED, ve GB'nda sırasıyla Therminol VP-1, eriyik tuz ve R141b kullanılmıştır. Bu sistem, termodinamiğin birinci ve ikinci yasalarına göre farklı parametreler göz önüne alınarak analiz edilmiştir. Daha sonra sistemin maliyet analizi Net Bugünkü Değer metodu kullanılarak gerçekleştirilmiştir. Sonuç olarak, POTGTG santralinin enerji ve ekserji verimlerinin azaldığı gözlemlenmiştir. Sistemin maliyeti 1.270.239.479 TL olarak hesaplanmıştır.

Anahtar Kelimeler-Parabolik Oluk Tipi Güneş Kolektörleri, Güneş Enerjisi, Organik Rankine Çevrimi, Net Bugünkü Değer

1*Sorumlu yazar iletişim: damla.kilic@bilecik.edu.tr (https://orcid.org/0000-0001-8728-1068) Makine Mühendisliği, Mühendislik Fakültesi, Bilecik Seyh Edebali Üniversitesi, 11230 Bilecik, Türkiye 2İletişim: oguz.arslan@bilecik.edu.tr (https://orcid.org/0000-0001-8233-831X) 


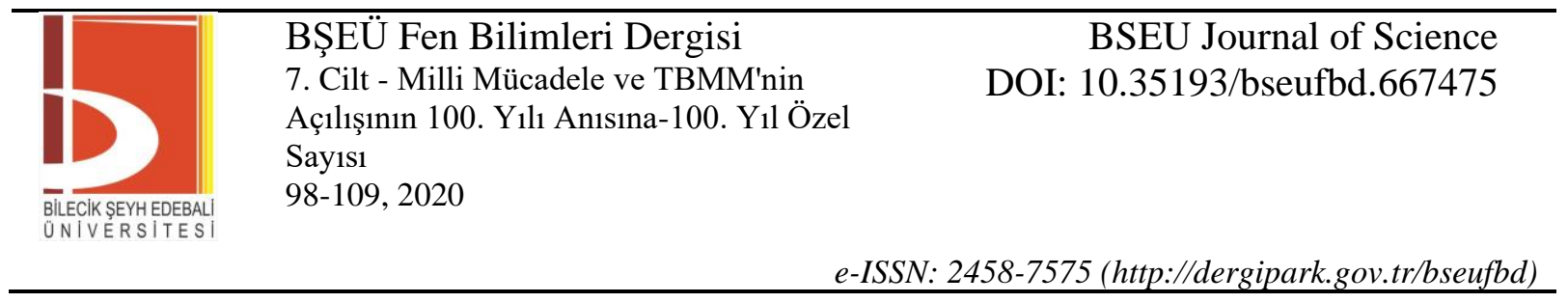

Makine Mühendisliği, Mühendislik Fakültesi, Bilecik Şeyh Edebali Üniversitesi, 11230 Bilecik, Türkiye

\title{
Potential Assessment of PTTSTP Plant in Bilecik
}

\begin{abstract}
In this study, a solar power plant design has made for a region with low solar radiation value. In the designed Parabolic Trough Type Solar Thermal Power (PTTSTP) plant has been taken into consideration a system operating according to the Organic Rankine Cycle (ORC). In the design of the PTTSTP plant has taken into consideration the solar radiation values of Bilecik. The system consists of the Solar field (SF), Thermal Energy Storage (TES) and Power Block (PB). The Therminol VP-1, molten salt and R-141b have used as a working fluid in the SF, TES and $\mathrm{PB}$, respectively. This system has been analyzed to considering different parameters according to the first and second laws of thermodynamics. And then cost analysis of the system has been made using the Net Present Value $(N P V)$ method. As a result of this study, the energy and exergy efficiencies of the PTTSTP plant were decreased with the temperature. The cost of the proposed system was calculated as 1.270.239.479 TL.
\end{abstract}

Keywords- Parabolic Trough Type Solar Collector, Solar Energy, Organic Rankine Cycle, Net Present Value 


\section{INTRODUCTION}

The world energy demand is increasing year by year in proportion to the increasing world population. Today $80 \%$ of the total energy production in the world is provided by fossil fuels (coal, oil, natural gas, etc.). Although fossil fuels have a high share of energy production, they are exhaustible sources. In addition, the use of these fuels increases the number of harmful gas emissions $\left(\mathrm{CO}_{2}, \mathrm{SO}_{2}\right.$, etc. $)$ and causes the greenhouse effect. Due to this kind of negativity caused by fossil fuels, renewable energy resources (solar, wind, geothermal, etc.), which are environmentally friendly and have unlimited resources, have gained importance in recent years.

Solar energy has the highest energy potential in renewable energy sources. Solar energy is used to generate heat and electricity. There are two ways to generate electricity using solar energy; Photovoltaic solar cells and Solar power plants. This study is based on solar power plants.

There are many studies on solar power plants in the literature. Some of these studies; Khaliq [1], examined the combined power and cooling cycle with solar energy. He used R141b as the working fluid in the design and analyzed the system according to the first and second laws of thermodynamics. As a result, the average energy efficiency of the system as $15.52 \%$ and the exergy efficiency as $7.33 \%$ were calculated. Binamer [2], developed the mathematical model of the EES program to evaluate the performance of the integrated solar combined power plant, which is planned to be established in Kuwait. As a result, the efficiency of the plant was higher than the traditional power plant in Kuwait and showed that it could reach more than 66\%. Poghosyan and Hassan [3], analyzed the techno-economic aspects of the Parabolic trough solar thermal power plant using SAM (Solar Advisor Model) software. They have also attempted to determine the optimal size of the thermal energy storage and solar field to minimize the contribution of the fuel supply system. De Luca et al. [4], worked on the configuration of two different (with and without TED) parabolic trough solar thermal power plant using thermal oil as primary heat transfer fluid. They examined in terms of annual energy production, annual productivity, capacity factor and total capital cost. Giostri et al. [5], compared the annual energy production and the performance of the design conditions for different solar field technologies. Senturk Acar and Arslan [6], have designed a power plant that operates according to the Organic Rankine Cycle, which is integrated with solar and geothermal energy, taking into account the Simav geothermal area. Then they have made energy and exergy analysis for different configurations of this system. As a result of the research, it has been calculated that $305.713 .5 \mathrm{kWh}$ of energy can be produced from the system. Boukelia et al. [7], designed a Parabolic trough type solar thermal power plant using Therminol VP-1 and Molten salt. The system has examined with and without integrated thermal energy storage and fuel backup systems. 8 different configurations created. The configurations are analyzed as Energy, Exergy, Economic and Environmental. As a result, the highest energy efficiency has obtained in the molten salt configuration. This system has thermal energy storage and fossil fuel back-up system. Karanfil and Ozbay [8], performed cost analysis of a $100 \mathrm{~kW}$ solar power plant using PV panels for Bilecik city. They also calculated the depreciation times according to the different usage areas of the system. Kumaresan et al. [9], In the present work, solar parabolic trough collector integrated with thermal storage unit is examined as experimental. The highest energy efficiency obtained from the system after 12 hours is $62.5 \%$. Reddy et al. [10], have made the PTTSTP Plant design and used the Therminol VP-1 as the working fluid. They conducted the energy exergy analysis of the system and evaluated it in different operating conditions to optimize the maximum efficiency of the plant. Gürtürk [11], made a cost analysis of a 1 MW solar power plant based on PV in Elazı̆̆. The payback period of the solar power plant is determined as 13 years. Present worth cost of the solar power plant is calculated as 1.156.763 US \$

In this study, a solar power plant design has made for a region with low solar radiation value. In the designed Parabolic Trough Type Solar Thermal Power (PTTSTP) plant has been taken into consideration a system operating according to the Organic Rankine Cycle (ORC) where solar energy is used as a heat source. In addition, the system has supported by a thermal energy storage system that can meet the required energy when solar energy is insufficient. This system has been analyzed to considering different parameters according to the first and second laws of thermodynamics. And then cost analysis of the system has been made using the Net Present Value (NPV) method. According to the obtained results, it has been discussed whether the system is suitable for investment. 


\section{MATERIAL AND METHOD}

The flow diagram of the designed power plant is given in Fig. 1. The working principle of the system is as follows; The sun's rays coming to the surface of the parabolic collectors are reflected in the receiving pipe in the center of the collector. In this way, the temperature of the fluid entering the parabolic collector rises. Then this fluid transfers heat from the heat exchanger to the refrigerant in the ORC. At high temperature and pressure, the refrigerant exiting the heat exchanger operates the turbine. And in this way, electrical energy is produced.

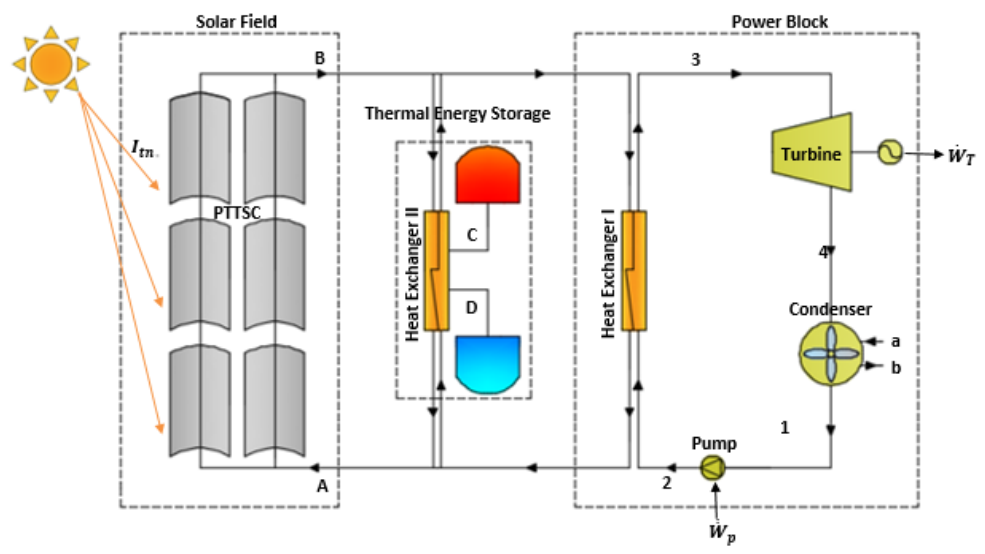

Fig.1. Flow chart of the system

The Therminol VP-1, molten salt and R-141b have used as a working fluid in the solar field (SF), thermal energy storage (TES) and power block (PB), respectively. The properties of the fluids are given in Table 1.

Table 1. Properties of fluids used in system design [12,13].

\begin{tabular}{lccc}
\hline Properties & Therminol VP-1 & Molten Salt & R141b \\
\hline Boiling Point $\left({ }^{\circ} \mathrm{C}\right)$ & 257 & - & 32.05 \\
Freezing Point $\left({ }^{\circ} \mathrm{C}\right)$ & 12 & 221.85 & -103.4 \\
Critical Temp. $\left({ }^{\circ} \mathrm{C}\right)$ & 400 & - & 204.35 \\
Critical Pres. $(\mathrm{MPa})$ & - & - & 4.21 \\
Density $\left(\mathrm{kg} / \mathrm{m}^{3}\right)$ & 1068 & 1840 & 458.56 \\
$\mathrm{C}_{\mathrm{p}}(\mathrm{kj} / \mathrm{kg} . \mathrm{K})$ & 1.53 & 1.56 & 1.15 \\
\hline
\end{tabular}

Parabolic trough type solar collectors have used in the solar field. The parabolic collectors, since it has a solar tracking system in the east-west direction, allows us to benefit from the sun rays for a longer period of time. The technical details of the parabolic collectors used in the designed system are given in Table 2. 
Table 2. Technical details of parabolic collectors [14].

\begin{tabular}{lc}
\hline Parabolic Collectors & Values \\
\hline Receiver outside diameter $\left(D_{o, r}\right)$ & $0.07 \mathrm{~m}$ \\
Receiver inside diameter $\left(D_{o, i}\right)$ & $0.066 \mathrm{~m}$ \\
Heat transfer coefficient inside the receiver $\left(h_{f i}\right)$ & $300 \mathrm{~W} / \mathrm{m}^{2}$ \\
Thermal conductivity of the receiver $(\kappa)$ & $16 \mathrm{~W} / \mathrm{m}^{\circ} \mathrm{C}$ \\
Transmissivity of the cover glazing $\left(\tau_{\text {cover }}\right)$ & 0.90 \\
Effective transmissivity of PTC $\left(\tau_{P T C}\right)$ & 0.94 \\
Absorptivity of receiver $\left(\alpha_{r}\right)$ & 0.87 \\
Correction factor for diffuse radiation $(\gamma)$ & 0.95 \\
Single collector width $(W)$ & 1.5 \\
Single collector length $(L)$ & 5 \\
\hline
\end{tabular}

In the design of the PTTSTP plant has taken into consideration the solar radiation values of Bilecik. Bilecik is located between $40.1^{\circ}$ latitude and $29.9^{\circ}$ longitude and has an average solar radiation value. In this study, the angle of inclination of the collectors was accepted as $45^{\circ}$. Accordingly, monthly radiation values that come to the collector surface used in the calculations are given in Table 3. Values of the south direction given in the table are used in calculations.

Table 3. Monthly radiation values.

\begin{tabular}{lcccc}
\hline \multirow{2}{*}{ Months } & \multicolumn{4}{c}{$\boldsymbol{I}_{\boldsymbol{t}}\left(\boldsymbol{W} / \boldsymbol{m}^{\mathbf{2}}\right)$} \\
\cline { 2 - 5 } Jouth $\left(\boldsymbol{\gamma}=\mathbf{0}^{\mathbf{}}\right)$ & West $\left.(\boldsymbol{\gamma}=\mathbf{9 0})^{\mathbf{}}\right)$ & North $\left(\boldsymbol{\gamma}=\mathbf{+ 1 8 0 ^ { \circ } )}\right.$ & East $(\boldsymbol{\gamma}=\mathbf{- 9 0})$ \\
\hline February & 1348.330 & 1304.508 & 1254.600 & 1304.508 \\
March & 1984.929 & 1951.733 & 1886.092 & 1951.733 \\
April & 2395.720 & 2383.971 & 2302.019 & 2383.971 \\
May & 2815.625 & 2821.051 & 2724.141 & 2821.051 \\
June & 2857.426 & 2870.575 & 2773.108 & 2870.575 \\
July & 2877.944 & 2887.715 & 2789.137 & 2887.715 \\
August & 2594.872 & 2589.897 & 2499.557 & 2589.897 \\
September & 2078.396 & 2053.756 & 1987.108 & 2053.756 \\
October & 1635.340 & 1591.549 & 1531.613 & 1591.549 \\
November & 1179.004 & 1127.075 & 1082.653 & 1127.075 \\
December & 1035.004 & 978.463 & 938.887 & 978.463 \\
\hline
\end{tabular}

As mentioned before, the system consists of a combination of ORC and solar energy. The main parameters of the system design are given in Table 4. The reference state has accepted $298.15 \mathrm{~K}$ and $101.325 \mathrm{kPa}$ in the thermodynamic analysis. Different parameters have been taken into account for turbine inlet temperature and pump outlet pressure. 
Table 4. Main parameters of PTTSTP plant

\begin{tabular}{cc}
\hline Parameters & Values \\
\hline Number of collectors & 500 \\
$T_{A}\left({ }^{\circ} \mathrm{C}\right)$ & 290 \\
$T_{B}\left({ }^{\circ} \mathrm{C}\right)$ & 390 \\
$T_{C}\left({ }^{\circ} \mathrm{C}\right)$ & 380 \\
$T_{D}\left({ }^{\circ} \mathrm{C}\right)$ & 280 \\
$P_{2}(\mathrm{kPa})$ & $700,850,1000,1150,1300$ \\
$T_{3}\left({ }^{\circ} \mathrm{C}\right)$ & $140,145,150,155,160$ \\
$\eta_{t h}$ & 0.88 \\
$\eta_{P}$ & 0.8 \\
\hline
\end{tabular}

\section{A. Modelling of Parabolic Trough Solar Collectors}

The modelling of parabolic trough solar collectors is based on the given in Eq.(1). The rate of useful energy delivered by a single collector is defined as [15]:

$$
Q_{u}=F_{R} \cdot\left[S \cdot A_{a}-A_{r} \cdot U_{L} \cdot\left(T_{i}-T_{a}\right)\right]
$$

Where $F_{R}$ is the heat removal factor, $S$ is the heat absorbed by the receiver, $A_{a}$ is the aperture area, $A_{r}$ is the receiver area, $U_{L}$ is solar collector heat loss coefficient, $T_{i}$ is the entering fluid temperature and $T_{a}$ is the ambient temperature. Then, the heat absorbed by the receiver is defined as:

$$
S=I_{t} \cdot \eta_{r}
$$

Where, $I_{t}$ is the direct irradiation intensity; and $\eta_{r}$ is the receiver efficiency defined as:

$$
\begin{aligned}
& \eta_{r}=\tau_{\text {cover }} \cdot \kappa \cdot \alpha_{r} \cdot \tau_{P T C} \cdot \gamma \\
& A_{a}=W \cdot L \\
& A_{r}=\pi \cdot D_{o, r} \cdot L
\end{aligned}
$$

The heat removal factor is given by:

$$
F_{R}=\frac{\dot{m}_{i} \cdot c_{p, i}}{A_{r} \cdot U_{L}}\left[1-\exp \left(-\frac{U_{L} \cdot F^{\prime} \cdot A_{r}}{\dot{m}_{i} \cdot c_{p, i}}\right)\right]
$$

Where $\dot{m}_{i}$ is mass flow rate of the Therminol VP-1 and $c_{p, i}$ is heat capacity of Therminol VP-1, $F^{\prime}$ is the collector efficiency factor defined as;

$$
F^{\prime}=\frac{\frac{1}{U_{L}}}{\frac{1}{U_{L}}+\frac{D_{o, r}}{h_{f i} D_{i, r}}+\left(\frac{D_{o, r}}{2 \kappa}+\ln \frac{D_{o, r}}{D_{i, r}}\right)}
$$

Where $D_{o, r}$ is the receiver outside diameter and $D_{i, r}$ is the receiver inside diameter.

\section{B. Energy Analysis}

For a continuous flow system, the mass balance is expressed in terms of the mass flow rate entering and exiting the system; 


$$
\Sigma \dot{m}_{i}=\Sigma \dot{m}_{o}
$$

Where $\dot{m}_{i}$ and $\dot{m}_{o}$ are the mass flow rates at inlet and outlet respectively.

For continuous flow systems, the conservation of energy in terms of energy entering and exiting the system;

$$
\dot{E}_{i}=\dot{E}_{o}
$$

In a continuous flow system, the energy conservation equation for the energy transmitted by heat, work and mass is written as follows;

$$
\dot{Q}+\dot{W}=\Sigma \dot{m}_{o} h_{o}-\Sigma \dot{m}_{i} h_{i}
$$

Where, $\dot{Q}$ and $\dot{W}$ are the net rate of heat and work, $\dot{m}_{o} h_{o}$ and $\dot{m}_{i} h_{i}$ are the enthalpy rates.

Energy efficiency is as follows [16];

$$
\eta=\frac{\dot{W}_{n e t}}{\dot{Q}_{i}}
$$

C. Exergy Analysis

General exergy balance;

$$
\Sigma \dot{E} x_{i}-\Sigma \dot{E} x_{o}=\Sigma \dot{E} x_{d}
$$

or

$$
\dot{E} x_{\text {heat }}+\dot{E} x_{\text {work }}+\dot{E} x_{m a s s, i}-\dot{E} x_{m a s s, o}=\dot{E} x_{d}
$$

The expression on the right side of equality refers to exergy destruction. The expressions on the left side of the same equation, exergy generated by the heat interaction $\left(\dot{E} x_{\text {heat }}\right)$, exergy generated by the interaction of the work $\left(\dot{E} x_{\text {work }}\right)$ and exergy entering $\left(\dot{E} x_{\text {mass }, i}\right)$ and exiting $\left(\dot{E} x_{\text {mass }, o}\right)$ the mass due to the mass flow is defined as follows;

$$
\begin{aligned}
& \dot{E} x_{\text {heat }}=\Sigma\left(1-\frac{T_{0}}{T}\right) \dot{Q} \\
& \dot{E} x_{\text {work }}=\Sigma \dot{W} \\
& \dot{E} x_{\text {mass }, i}=\Sigma \dot{m}_{i} \psi_{i} \\
& \dot{E} x_{\text {mass }, o}=\Sigma \dot{m}_{o} \psi_{o}
\end{aligned}
$$

Exergy flow is calculated as follows;

$$
\psi=\left(h-h_{0}\right)-T\left(s-s_{0}\right)
$$

Where $h_{0}$ ve $s_{0}$ refer to enthalpy and entropy values of the fluid at the dead state pressure and temperature, respectively. 
Exergy efficiency can be defined as the ratio of total exergy output to total exergy entry [16];

$$
\varepsilon=\frac{\dot{E} x_{\varsigma}}{\dot{E} x_{g}}=1-\frac{\dot{E} x_{d}}{\dot{E} x_{g}}
$$

\section{Net Present Value (NPV)}

In this method, the cash flows of the project to be invested are determined according to the time value of money. Investments incurred as a result of cash outflow are taken as negative and earnings are taken as positive and a net result is obtained. If the result is negative, the investment project cannot be made and if it is positive, the decision to make is correct.

While cost analysis of the designed system, the cost of the initial investment, the operating cost and the cost of scrap after completing the life of the system have been taken into consideration.

The initial investment cost of the system consists of the cost of the solar field $\left(C_{s f}\right)$, the cost of the thermal energy storage system $\left(C_{t e d}\right)$, the cost of the power block $\left(C_{p b}\right)$ and the montage cost $\left(C_{m}\right)$.

Total cost $\left(C_{t}\right)$;

$C_{t}=C_{s f}+C_{t e d}+C_{p b}$

$C_{s f}, C_{t e d}$ and $C_{p b}$ values have been included to the calculation as $270.00 \$ / \mathrm{m}^{2}, 30.00 \$ / \mathrm{kWh}$ and 830.00 $\$ / \mathrm{kWe}$, respectively[18]. USD exchange was conducted based on Turkey's Central bank data on August, 2018 (1 $\mathrm{USD}=5.27 \mathrm{TL}$ ). The cost of montage is taken as $10 \%$ of the total cost. Accordingly, the initial investment cost is as given in the equation below;

$$
C_{i}=C_{t}+C_{m}
$$

In the cost analysis of the plant, the cost of electricity of the pump, personnel expenses, cooling fluid cost, maintenance and repair costs constitute the operating costs of the system [17].

The cost of maintenance and repair of the cooling system is determined as $2 \%$ of the initial investment cost [16]. Accordingly, the cost of maintenance and repair;

$$
C_{m r}=\frac{C_{i}}{100} \cdot 2
$$

The labor force requirement of the power plant has been included in the calculations by considering 1 manager, 1 engineer and 9 workers to meet the system operation. The minimum wage average of 2019 is based on (2558.4 TL). According to this, the total annual personnel expenses [17];

$$
C_{p}=2558.4 \cdot 12 \cdot(5 \cdot 1+3 \cdot 1+1.5 \cdot 9)
$$

While calculating the cost of electricity for the system, the unit cost of electricity was included in accounts as $0.69 \mathrm{TL} / \mathrm{kWh}$. Accordingly, the cost of electricity;

$$
C_{e}=W_{p} \cdot 0.69 \cdot 24 \cdot 360
$$

The total operating cost of the system;

$$
C_{o}=C_{m r}+C_{c}+C_{p}+C_{e}
$$

The scrap cost of the plant was taken as $10 \%$ of the initial investment cost. Accordingly, the cost of scrap; 


$$
C_{s}=\frac{C_{i}}{100} \cdot 10
$$

The useful life of the PTTSTP plant has been determined as 20 years and the cost of the system was investigated by the NPV method. NPV method can be expressed mathematically as follows;

$$
N P V=\sum_{t=0}^{n} \frac{B_{t}}{(1+r)^{t}}
$$

$N P V$; Net present value, $\mathrm{n}$; the useful life of the project, $B_{t}$; cash flow in $t$ year, $r$; discount rate.

\section{RESULT AND DISCUSSION}

In this study, parametric evaluations were made for pressure values at pump inlet (1) and temperature values at heat exchanger outlet (3) while PTTSTP plant design was performed. The system had established considering that it could be placed 500 collectors on the land of $138.330 \mathrm{~m}^{2}$ in Bilecik province.

In this context, energy efficiency, exergy efficiency and net power output changes were examined and cost analysis was performed by the $N P V$ method. The system was analyzed according to the first and second laws of thermodynamics. Accordingly, the change in energy efficiency according to the temperature $T_{3}$ is shown in Fig.2, the change of exergy efficiency according to the temperature $T_{3}$ is shown in Fig.3.

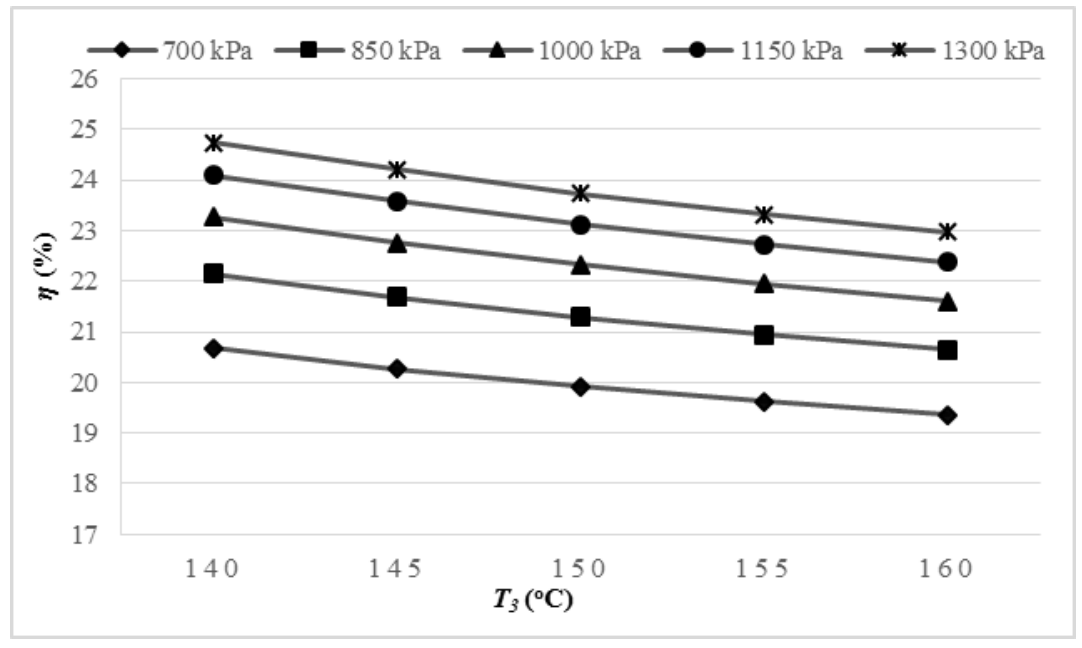

Fig. 2. The variation of $\eta$ versus $T_{3}$.

Figure 2 shows that the energy efficiency of the PTTSTP plant decrease by the increase in working fluid temperature. The energy efficiency of the system ranges between 19.36 and $24.73 \%$. The highest efficiency value is $24.73 \%$ at a pressure of $1.3 \mathrm{MPa}$ and at a temperature of $140{ }^{\circ} \mathrm{C}$ and the lowest efficiency value is $19.36 \%$ at a pressure of $0.7 \mathrm{MPa}$ and at a temperature of $160^{\circ} \mathrm{C}$. 


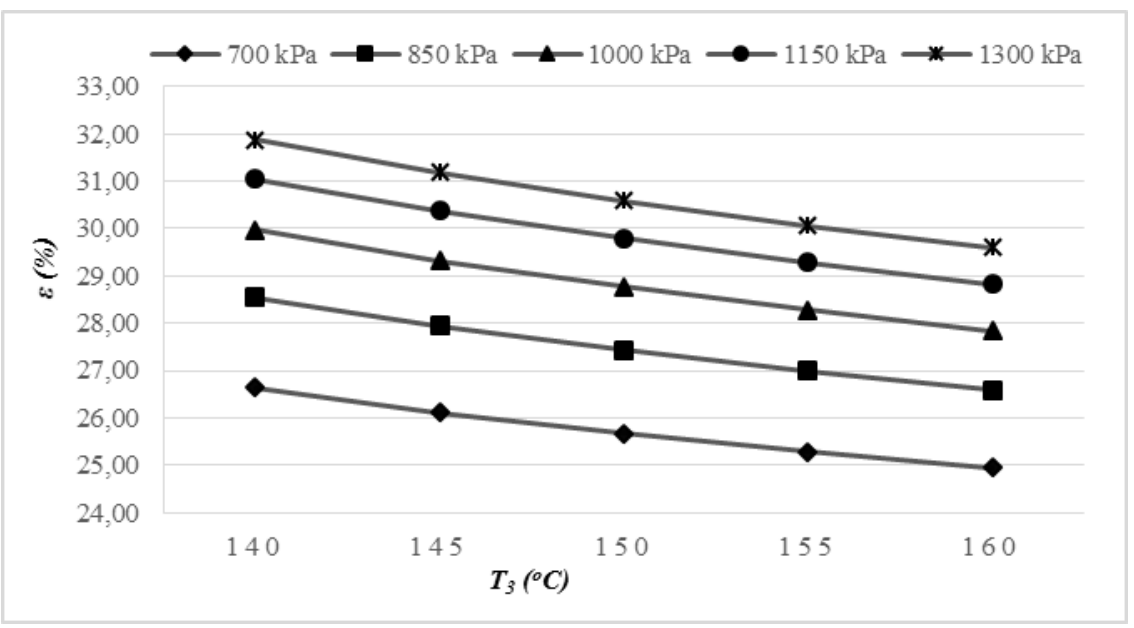

Fig.3. The variation of $\varepsilon$ versus $T_{3}$.

Figure 3 shows that the exergy efficiency of the PTTSTP plant decrease by the increase in working fluid temperature. The exergy efficiency of the system ranges between 24.95 and $31.86 \%$. The highest efficiency value is $31.86 \%$ at a pressure of $1.3 \mathrm{MPa}$ and at a temperature of $140{ }^{\circ} \mathrm{C}$ and the lowest efficiency value is $24.95 \%$ at a pressure of $0.7 \mathrm{MPa}$ and at a temperature of $160^{\circ} \mathrm{C}$.

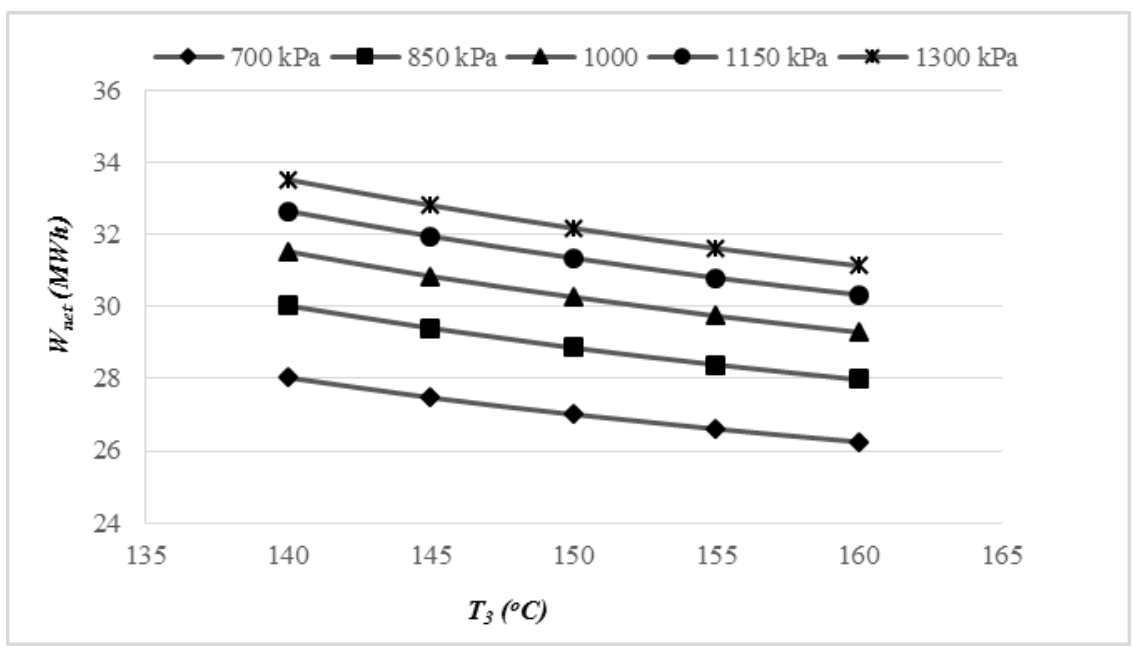

Fig.4. The variation of $W_{\text {net }}$ versus $T_{3}$.

Figure 4 shows that the net electrical energy production values of the PTTSTP plant decrease by the increase in working fluid temperature. The net electrical energy production of the system ranges between 26.25 and 33.52 MWh. The highest the net electrical energy production is calculated $33.52 \mathrm{MWh}$ at a pressure of 1.3 $\mathrm{MPa}$ and at a temperature of $140{ }^{\circ} \mathrm{C}$.

When the obtained data were examined, the best values of the system had obtained at a pressure of 1.3 $\mathrm{MPa}$ and at a temperature of $140{ }^{\circ} \mathrm{C}$. Accordingly, the data obtained from the cost analysis of the system had given in Table 5. The table does not include the values of the intermediate years. 
As a result of the calculations made according to today's values, the values given in Table 5 were obtained. Accordingly, it is possible to reap a profit of 1.270.239.479 TL. As a result, the system is suitable for investment since it can amortize itself within 5 years. But collector prices are expensive for countries with high interest rates. Therefore, it is necessary to take into account parameters such as interest rates and exchange rates that hinder investment.

Table 5. NPV analysis of system design (TL)

\begin{tabular}{|c|c|c|c|c|c|}
\hline Investment & Today & 5 & 10 & 15 & 20 \\
\hline Solar Field cost & -19.681 .481 & & & & \\
\hline TES cost & -61.418 .253 & & & & \\
\hline $\mathrm{PB}$ cost & -14.408 .351 & & & & \\
\hline Total cost & -95.508 .086 & & & & \\
\hline Montage cost & -9.550 .808 & & & & \\
\hline Scrap cost & -10.505 .889 & & & & \\
\hline Initial Investment cost & -105.058 .894 & & & & \\
\hline \multicolumn{6}{|l|}{ Cash Flow (TL) } \\
\hline Refrigerant cost & -1.440 .835 & & & & \\
\hline Maintenance and repair cost & -2.101 .177 & -105.058 & -105.058 & -105.058 & -105.058 \\
\hline Personnel expenses & -844.272 & -844.272 & -844.272 & -844.272 & -844.272 \\
\hline Electricity Production & 198.428 .926 & 198.428 .926 & 198.428 .926 & 198.428 .926 & 198.428 .926 \\
\hline Total cash flow & -117.005 .619 & 197.479 .595 & 197.479 .595 & 197.479 .595 & 197.479 .595 \\
\hline Discount rate $(\% 13)$ & 1.00 & 0.54 & 0.29 & 0.16 & 0.09 \\
\hline Cumulative cash flow & -117.005 .619 & 870.392 .357 & 1.857 .790 .334 & 2.845 .188 .310 & 3.832 .586 .287 \\
\hline Present Value & -117.005 .619 & 107.184 .012 & 58.175 .187 & 31.575 .161 & 17.137 .732 \\
\hline$N P V(T L)$ & & & 1.270 .239 .479 & & \\
\hline
\end{tabular}

\section{CONCLUSION}

In this study is investigated the applicability of the PTTSTP plant in Bilecik. In this aim, energy, exergy and NPV analysis were conducted. The energy and exergy efficiencies of this system were found as $24.73 \%$ and $31.86 \%$, respectively. When the useful life of the PTTSTP plant was determined as 20 years, the NPV value was calculated as 1.270.239.479 TL. According to the results obtained from the analyzes for considered location, it is seen that the location is suitable for solar power plant. However, To invest in the PTTSTP plant only technical parameters such as sunshine time and solar radiation values are not enough. The economic situation of the country should also provide investment conditions.

\section{REFERENCES}

[1] Khaliq A. (2017), "Energetic and exergetic performance investigation of a solar based integrated system for cogeneration of power and cooling", Applied Thermal Engineering, 112, 1305-1316.

[2] Binamer, A.O. (2019), “Al-Abdaliya integrated solar combined cycle power plant: Case study of Kuwait, part I", Renewable Energy, 131, 923-937.

[3] Poghosyan, V. and Hassan, M.I. (2015), "Techno-economic assessment of substituting natural gas based heater with thermal energy storage system in parabolic trough concentrated solar power plant", Renewable Energy, $75,152-164$.

[4] Luca, F.D., Ferraro, V., Marinelli,V. (2015). "On the performance of CSP oil-cooled plants, with and without heat storage in tanks of molten salts”, Energy, 83, 230-239. 
[5] Giostri, A., Binotti, M., et al. (2012). "Comparison of different solar plants based on parabolic trough technology”, Solar Energy, 86, 1208-1221.

[6] Acar, M. S., \& Arslan, O. (2019). Energy and exergy analysis of solar energy-integrated, geothermal energypowered Organic Rankine Cycle. Journal of Thermal Analysis and Calorimetry, 137(2), 659-666.

[7] Boukelia,T.E., Mecibah, M.S., Kumar, B.N., Reddy, K.S. (2015). "Investigation of solar parabolic trough power plants with and without integrated TES (thermal energy storage) and FBS (fuel backup system) using thermic oil and solar salt", Energy, 88, 292-303.

[8] Özbay, H., \& Karafil, A. (2019). “Cost Analysis of PV Power Plant for Bilecik City”, BSEU Journal of Science, $6(2)$.

[9] Kumaresan, G., Sridhar, R. and Velraj, R. (2012). "Performance studies of a solar parabolic trough collector with a thermal energy storage system", Energy, 47, 395-402.

[10] Siva Reddy, V., Kaushik, S.C. , Tyagi, S.K. (2012). "Exergetic analysis and performance evaluation of parabolic trough concentrating solar thermal power plant (PTCSTPP)", Energy, 39, 258-273.

[11] Gürtürk, M. (2019). Economic feasibility of solar power plants based on PV module with levelized cost analysis. Energy, 171, 866-878.

[12] Cakici, D.M. (2016). “Thermal Modelıng of A Geothermal Powered Organıc Rankıne Cycle Integrated With Parabolıc Trough Solar Collectors”, Master of Science, Izmir, Turkey.

[13] Sohal M.S., Ebner, M.A., Sabharwall, P., Sharpe, P. (2010). "Engineering Database of Liquid Salt Thermophysical and Thermochemical Properties", Idaho National Laboratory.

[14] Yuksel, Y.E. (2018). "Thermodynamic assessment of modified Organic Rankine Cycle integrated with parabolic trough collector for hydrogen production", International Journal of Hydrogen Energy, 43, 58325841.

[15] Kalogirou, S.A., Solar energy engineering: Process and system. USA: Elsevier.

[16] Cengel, Y.A., Boles M.A. (1996), Thermodynamics: An Engineering Approach Translation from 2nd Edition, Translated by: Taner Derbentli, McGraw-Hill- Literature Publishing, İstanbul.

[17] Tugcu, A., Arslan, O., Kose, R., Yamankaradeniz, N. (2016)."Thermodynamics and Economical Analysis of Geothermal Assisted Absorption Refrigeration System: Simav Case Study”, Journal of Heat Science and Technique, 36, 1, 143-159.

[18] Boukelia, T. E., Arslan, O., \& Mecibah, M. S. (2017). Potential assessment of a parabolic trough solar thermal power plant considering hourly analysis: ANN-based approach. Renewable Energy, 105, 324-333. 